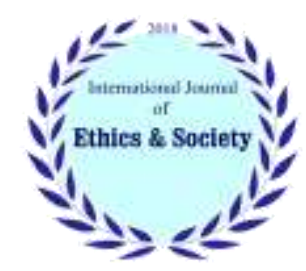

International Journal of Ethics \& Society (IJES)

Journal homepage: $\underline{\text { www.ijethics.com }}$

Vol. 3, No. 1 (2021)

\title{
Ethics and Excuse in Contract Execution in Iranian Civil \& Commercial Law
}

\section{Amir Abbas Mirzaei, Abdolrahim Moradi ${ }^{*}$, Alireza Saberian}

Dept. of Law, Faculty of Humanities, Semnan Branch, Islamic Azad University, Semnan, Iran

\section{Abstract}

Background: Basically, in any contract, the parties estimate their potential profit and loss and then enter into a contract. However, sometimes the circumstances and circumstances of the time of the contract change so much and make the implementation of the contract heavy and costly. In these circumstances, the implementation of the contract is difficult. This study aimed to investigate the difficulty of contract implementation in Iranian Civil code and commerce from an ethical perspective.

Conclusion: In jurisprudence, there is a special rule called "invalidity of the whole contract with the excuse of fulfillment in content", which has become one of the general rules of contracts in jurisprudence. This rule implies the concept that if after the conclusion of the contract, the fulfillment of the obligations arising from the contract becomes impossible forever, the implementation of the content of the contract and its obligations is not necessary and the transaction is void. Iranian law deals with this issue in Articles 227 and 229 of the Civil Code, and conditions such as foreignness and the inevitability and unpredictability of the excuse are considered for the realization of the title of excuse for the execution of the contract. The realized excuse, as the case, will cause the contract to be dissolved or its execution to be suspended until the obstacle is removed.

Keywords: Contract execution, Civil code, Excuse, Ethics

\section{Introduction}

In addition to the personal and individual aspects of human beings, they are social creatures. Their plans, goals, and lives are indescribably intertwined. In other words, human survival and spiritual and material comfort are owed to the rational and correct management of this relationship. Ethics and law are considered as normative systems for this management. The relationship between ethics and law has long been a serious focus of the philosophy

* Corresponding Author: Email: amirabbasmirzaei67@gmail.com

Received: 11 Feb 2021

Accepted: 13 Mar 2021 
of law, so that today, the school of ethics and law is recognized as one of the most important schools of philosophy of ethics in Europe. On the other hand, in contrast to the school of legal ethics, the philosophical theory of positivism makes a complete distinction between the standard of the legal norm and the standard of the moral norm and believes that even a common system of evil norms can be considered as a legal system (1).

Ethical, religious, and religious rules and requirements govern every contract, treaty, agreement, treaty, contract, and covenant. Ethical instructions and considerations, religious and customary rules, and customs must be observed in all contracts and at all stages (before the contract - during the contract - after the contract). If we only think about strengthening the contract and amending it legally and economically, and only use the material and legal accounts and books as a criterion and do not pay attention to ethical issues, then the contract will have a problem that does not take into account. We did. Sometimes a person who is harmed by a transaction, like a tsunami, breaks down all the legal barriers designed by the best lawyers in our favor. In principle, in any contract, the parties estimate their potential profit and loss and then enter into a contract. However, sometimes the circumstances of the time of the contract change so much that the execution of the contract is so heavy and costly that no far-sighted person can predict it. In such a situation, the resulting loss is unusual and unforeseen; therefore, there does not seem to be a basis for the necessity of belief. In such circumstances, observance of ethics is one of the requirements of contracts.

Contractualism is one of the most traditional criteria for justifying moral propositions, which has always had defenders throughout the history of ethics, and even now some people strongly defend it. Although there are many different ways and methods of this name, in general, it can be said that moral contractualism is a set of theories to justify moral beliefs that is the criterion for the justification of morality (or at least part of the rulings). They seek morality (such as justice) in the rational agreement of individuals. Contractors argue that a moral belief is justified only if certain people agree on it in certain circumstances, or on the rule or system that it contains; Regardless of whether the result of this agreement is consistent with previous beliefs or not (2).

\section{The concept of the contract.}

The contract is called "convention" in French and "al-Ittifaq" in Arabic. Many law professors equate a contract with a contract and some differences between them, such as:

1- In Iranian law, a contract mostly refers to certain contracts, but the contract includes all contracts, both definite and indefinite (3).

2. A contract is used for contracts that create an obligation but the agreements that are concluded to terminate the obligation are called contracts, not contracts. If this difference is accepted, the contract includes the contract. That is, the contract is concluded to create an obligation and also to eliminate the obligation, but concluding a contract is only to create an obligation.

In a general definition, a contract is an agreement of two compositional wills to create a legal effect in the world of credit. Therefore, what belongs to the intention of the parties is the same legal effect that as a result of the creation of this legal effect, obligations are also created for each of the parties. According to the definition of obligation given by some jurists, an obligation is a legal relationship according to which a person can ask others to do something (4). To do so is to oversee the act, to abandon the act, and to transfer the property, which is the subject of the obligation. For example, in a contract of sale, the transfer of ownership belongs to the intention of the parties. By creating this effect in the world of credit and the realization of the contract of sale, obligations will be imposed on the parties to the contract, such as the surrender of the seller and the surrender of the price. The direct and immediate subject of the contract is the same as the legal relationship, but the subject of the obligation, deed, omission, or transfer of property is a branch of the subject of the contract. Denying the transaction or assigning it to a commitment is not an accurate opinion. The subject of the transaction is a set of operations and legal developments for 
which there is a compromise. For example, in exchange, the exchange of two properties, and in buying and selling, the purchase of the seller for the price, etc., is the subject of the transaction. The subject of the transaction can be taking on another religion or granting a proxy for the transaction. Now, as a result of agreeing on these issues, obligations arise for either parties or one of them, which can be the surrender of property or the performance of a certain task (5). What is more desirable, then, is the separation of these two concepts from each other, given that not all obligations arising from a contract (6).

Dehkhoda has defined a contract or contract as follows: A contract or contract means having a fixed, appointed, and established stability, a promise, a condition, and a contract. According to Article 183 of the Civil Code: A contract is that one or more people commit an obligation to one or more other people and it is accepted by them. From the point of view of jurists, a contract is an agreement between two necessary wills to create a legal effect. If two wills are necessary, the contract will be fulfilled (7).

In other words, a contract is synonymous with a contract, and a single contract is a word for contracts, which has been transferred from Arabic to Persian and means to close. The literal meaning of the contract includes covenants, ownership, financial, non-financial, exchange, and non-exchange, and also includes agreements that are realized to eliminate the effect of inventory. In the lexical meaning of the contract, we have no reason for the Iranian legislature to intervene, so the same lexical meaning is the argument, and the authenticity of this lexical concept compensates for the defect in the definition in Article 183 of the Civil Code. It is general in Article 183 of the Civil Code, but outside of Article 183, the Iranian legislature generally means wherever it uses a contract or contracts without a counterpart, it means the lexical meaning of the contract, so the contract and the contract have the same meaning. Defined a legal agreement of two or more parties on a particular issue to create a joint legal effect. A contract is a bilateral legal act that takes place when the parties freely enter into negotiations with each other and reach an agreement. A contract is an agreement between two necessary wills to create a legal effect. In other words, whenever to create a legal effect such as sale, lease, etc., the necessary intersection and conciliation of two wills are required, the contract is concluded. A contract is that one or more people against one or more other people. Agree to do something and be accepted by them. The agreement of two or more people is the main part of the definition of the contract. For example, in buying a car, two people agree that one (seller) gives his car to another (buyer) and the other reciprocally pay money to the seller (8).

\section{Ethics in contracts:}

Ethics in the plural of the word creation means goodness and in the literal meaning refers to the science of ethics, which is one of the disciplines of philosophy "(9). Since every voluntary act of man can be evaluated with moral values, legal issues that are part of human inseparable actions can also be subject to moral judgments. The realm of ethics is wider than law, and violations of moral norms have no guarantee of enforcement, contrary to legal rules. Of course, creative principles can enter the field of law by becoming general legal principles and be guaranteed. Value principles such as the principle of fairness, the principle of peaceful resolution of disputes, the principle of sovereignty of the will, the principle of good faith, and gradually morality have entered the law. Some have become legal rules. The importance of these ethical principles is such that if the parties in the investment contract have determined the ruling law determined by the ruling law but it is vague or silent, these principles can be invoked and the resulting dispute can be resolved.

In the case of contracts, the rule of will means that individuals are free to ally in any way they wish, and that treaty is enforced and respected by the collective will of society. Accepting the principle of contractual freedom does not mean denying the rule of law, but it does mean that the legislature, for practical consequences, has accepted respect for the consent of individuals so that contractual freedom is regarded as a principle. Therefore, it can be seen 
in Article 10 of civil code. Considered the compromise resulting from contractual freedom to be valid and respectable to the extent that it is not contrary to law, public order, and good morals, and in Article 975 of the same law, obliges the courts to prevent the implementation of contracts contrary to public order and good morals (10).

If the principle of contractual freedom cannot be properly exploited, reason dictates that it be limited. Therefore, today in most legal systems, we see that the execution or conclusion of the contract is prevented due to opposition to the law or good morals or public order. These three factors limit human freedom in concluding a covenant. Restriction of contractual freedom to the point of opposition to public order does not seem to conflict with justice, but the relative nature of the concepts of public order and morality and the various definitions and interpretations of the two raises concerns that justice may not be violated. If we look at the behavior of governments and societies, it will be clear that in most countries, the increasing involvement of governments in economic affairs has expanded the concept of public order and reduced the freedom of individuals to enter into contracts. The law annuls many contracts or imposes unwanted conditions on the parties, to the extent that some jurists have added "compliance of the contract with social necessities and public order" to the basic conditions of contract validity (11).

One of the most important and central epistemological issues of moral propositions is the question of the criterion for their justification. In general, it can be said that four different criteria for justifying moral propositions have been proposed by moral epistemologists: intuitionism, coherence, contracts, and fundamentalism (12).

Contractualism, as an independent and coherent view, does not last long in explaining the origin of moral precepts. But a look at the history of rational reflections on ethics shows that there have been tendencies among thinkers to agree on the truth of contract and agreement on the origin of morality. Naturally, like many moral views, the roots of this view must first be traced to the works of ancient Greece. The idea is often traced back to the Greek sophists of the time of Socrates, on the standard of justice and oppression (13).

Anti-positivist philosophical theories, including the school of natural law, emphasize that law is fundamentally related to ethics. Ethics teaches us that we must support good faith and fight against malice and fraud. When a moral rule fails to take on a legal form, it may remain colorless and a natural obligation at the border of law. The difference between law and morality is not in their territory, nature, and purpose, but in their practice. It becomes a legal rule. The exact separation of law and ethics is not possible. Ethics is not only effective in preparing a legal rule, but also plays a role in its implementation and interpretation, and if the legislator silences something or violates the moral rule, the judge will compensate it through interpretation. Thus, ethics is one of the main elements of law and all their efforts and claims are not without the need of ethics despite technical legal rules (14).

According to ethics, the most important role of which is good faith, judges can use it to modify the content of the contract and adapt it to new conditions and circumstances. The main focus is on making ethical adjustments in the implementation or non-implementation of a contract that has been concluded with certain circumstances in terms of social, economic, legislative, monetary, and banking conditions, and in this situation, especially in longterm contracts until the contract is executed. There is a fundamental change that makes the implementation of the contract difficult for oblige and causes a huge and unreasonable loss. In moral adjustment, the goal is to observe justice and fairness and to harmonize the contract with the new economic conditions, and restore the balance that has been disturbed after the conclusion of the contract (15). In Article 230 AH. It is stated in Iran: "If it is stipulated in the transaction that in case of violation, the violator will provide a sum of money as damages, the ruler cannot sentence him to more or less than what be required." Thus, one of the important roles of ethics is to give the judge the authority to adopt the contract and other legal rules to the circumstances and requirements of the event so that an unfair and unreasonable result is not imposed on one of the parties.

4

Available at: www.ijethics.com 


\section{Conditions for the exclusion of contract im-} plementation in Iranian law:

Conditions are necessary for the realization of the excuse for the execution of the contract because just any inability to execute in the contract does not cause the exclusion of its execution and as a result, any impossibility of execution will not cause the termination of the contract.

In general, the cancellation of the performance of the contract has elements that cause special effects and the dissolution of the contract and the loss of liability of the obligor, and as a result, justifies the impossibility of fulfilling aforesaid man obligation. These elements are the structure and pillars of the contract execution:

A- Being foreign causes the excuse or non-interference of the will and action of the contractors in creating it

B- Inevitability of excuse

C - Its unpredictability (16)

A. Non-intervention of oblige or the external nature of the accident the externality of the accident means that the excuse should not be the result of obliges action, and also the reason that makes the contract impossible and non-fulfillment of obligations arising from it Have a commitment. Otherwise, and if this cause is the result of the actions of the obligated person, he will still be responsible for non-performance of the contract and his responsibility in this regard will not be lost and he will be deprived of the ability to invoke the exclusion of the contract. Article 227 of the Civil Code of Iran states that: "A violator of an obligation when he is sentenced to pay damages that he cannot prove that the non-performance was due to an external cause that cannot be attributed to him ». But in the interpretation of being a foreigner, two views have been expressed so far. The first view - the accident should be outside the scope of the committed activity and its benefit.

The second view - the accident must be outside the will and performance of the perpetrator so that the accident cannot be attributed to the intent or fault of the aforesaid man (17).

In explaining the first view, it should be stated that the criterion for assessing whether an accident is foreign or not is the lack of connection between that accident and the perpetrator. Wherever the fulfillment of the apology is related to the committed person or the committed activities, the said excuse and incident are not external to him. The survivor is responsible for the impossibility of performing the contract. It is observed that if such a view is accepted, the strike will not be considered as an excuse for the fulfillment of the obligation, since it takes place in the field of activity and scope of the obliging institution, although legally no fault can be attributed to the oblige. But if the second view is adopted, the result will be different, because according to the second view, which is based on the theory of fault, the mere fact that the incident was related to the obligor and his field of activity will not prevent the apology.

But some argue that "it is an incident that is external and outside the authority of oblige" (16). Elsewhere they state: "It does not seem to be internal or external, but the incident must be attributable to oblige. And should not be attributed to the obligor (16). Accuracy in what the jurists have said implicitly or explicitly proves that such a condition has been valid for them to be relieved of responsibility. Also, the acceptance of the impossibility of attributing the incident to a certain person by the jurists indicates that the externality of the incident is accepted by the jurists (17)

B- The inevitability of an accident that occurs and causes the exclusion of the contract, must be an irreparable and irresistible accident and cannot be resisted if the contractor, assuming his ability to prevent the occurrence of the accident, take action Does not give and does not prevent the realization of the mentioned incident, he will remain responsible for the non-execution of the contract, because he has committed a mistake in fulfilling his obligation (18).

Article 229 of the Iranian Civil Code explicitly mentions and states this condition; "If the obligor is unable to fulfill his obligation due to an accident, the resolution of which is beyond his authority, he will not be sentenced to pay damages."

According to the mentioned article, if the obligor can overcome the mentioned obstacle and escape from it but does not do so, the excuse of execution will not be fulfilled and as a result, the aforesaid 
man will remain responsible for not fulfilling his obligation (19).

From the appearance and rationale of Article 229 of the Civil Code, it is inferred that the inevitability of an accident, regardless of the source alone, will cause the obligor to absolve himself of responsibility for not fulfilling his obligation, such an illusion may also exist in Article 227. Come on. Therefore, the mere fact that the incident is external and its inevitability can be considered as absolving oneself on one's own, and the realization of one of the above-mentioned titles is sufficient to absolve the obligor from liability, but such an interpretation will have undesirable consequences (18). This assumption is separable into two; Assumption that the realization and creation of an obstacle are due to the committed action, but the repulsion and neutralization of the said incident are beyond his authority and another assumption is that the cause of realization is an external accident and is not the result of the committed action, but oblige despite the ability It does not attempt to avoid the obstacle and does not avoid the mentioned liquid. In both cases, the liability will remain the same and he will be responsible for non-performance. This condition also has a jurisprudential basis and has been recognized in various forms. The jurists have stated in this regard that it is not acceptable to cite the excuse of not being able to execute the contract if it is possible to oppose and reject it (20).

C. The unpredictability of this condition means that the occurrence of the incident causing the excuse in custom is reasonably unpredictable (18). In the legal system of our country, since such a condition is not mentioned in the issue of damages due to non-fulfillment of obligations, it is doubtful. A group of lawyers believes that such a condition exists in the fulfillment of an excuse. This group believes that since this part of the Civil code of our country is adapted from the French Civil code, the existence of such a condition can be considered necessary in their rights, and this can be achieved by a comprehensive interpretation of Article 227 of the Civil Code. As a result, the unpredictability of the accident can be considered as a condition of exemption (18).

6

Available at: www.ijethics.com

\section{Conclusion}

Sometimes the performance of a contractual obligation as a result of unforeseen and uncontrollable events, without being physically impossible, becomes economically difficult and costly, and the contractual balance is disturbed.

This issue is raised in different legal systems with different titles such as the theory of unpredictability and severe and unexpected difficulty. However, the approach of different legal systems to such a situation is not the same. Although all legal systems more or less agree on the fact that the ruling on the necessity of a contract in such a situation is unfair and immoral, and they cite different principles in justifying it, but the solution of these systems and the adopted principles are different. Some legal systems have accepted the solution of dissolving the contract by granting an exemption to resolve the issue, and others have raised the issue of amending the contract.

In general, it sometimes happens that after concluding the contract correctly and the contractors commit to the obligations arising from the contract, events occur that make it impossible to fulfill the contractual obligations. It is also clear that the commitment to the impossible is an irrational, immoral, and futile commitment that is legally invalid. As a result, the adherence of the contractors to the contract on the assumption that its implementation is impossible is reprehensible and unethical. Fairness and justice are two moral concepts that are very similar and sometimes used interchangeably. But it should be known that justice has more to do with rights. The rules of justice are like universal rights, to the extent that many scholars have considered the purpose of each one as one, and some have not seen a separation between them. Observance of ethical points and the rule of fairness in contracts is more important than legal points and relying on lawyers and legal advisers and lawyers. These points should be searched more in the books of ethics and religious rules, but some of the most important ones are:

The lawfulness of the transaction, fairness, telling the truth, making it easy, not entering into another 
transaction, keeping the promise, fulfilling promises, avoiding usury, refraining from underselling and overselling, not swearing right, not swearing, not lying Do not go to extremes, do not indulge in other sex, avoid transactions to the detriment of the country's economy such as currency brokerage, refrain from verbal and verbal transactions, do not impose contract terms on the weak and distressed party, do not deceive the party, suffice to normal profit Not being a wolf in the transaction, not trading in some times and places such as during Friday prayers or the mosque, refraining from fainting and impure sex, changing the balance and amount, observing the interests of the other party, avoiding forbidden and suspicious transactions and Against the law.

In jurisprudence, there is a special rule called "invalidity of the whole contract with the excuse of fulfillment in content", which has become one of the general rules of contracts in jurisprudence. It is always impossible to execute the content of the contract and its obligations, it is not necessary and that transaction is void and there is no difference between contracts and this rule will apply to all contracts, even permission contracts. The matter has been addressed and conditions have been set for the realization of the title of excuse for the implementation of the contract, without which they cannot rely on this rule. Assuming the community meets the necessary conditions for the fulfillment of the obligation, the parties will be released from fulfilling the obligations.

In Iranian law, the jurisprudential rule of "invalidation of the whole contract with the excuse of the fulfillment of the meaning" is interpreted as the excuse of fulfilling the obligation, and the following conditions are considered necessary for the fulfillment of the obligation.

1 - Being foreign causes the excuse or non-interference of the will and action of the contractors in creating it

2. Excuse is inevitable

3- Its unpredictability. Carefully in what the jurists have stated, it can be understood that the above conditions, i.e. being foreign and inevitable and unpredictable, have jurisprudential bases and in various ways, these conditions have been considered necessary by them to fulfill the excuse of execution. According to what has been stated in jurisprudence, in the law of the subject, the realization of the excuse is realized according to the type of excuse, depending on the case, it will cause the dissolution of the contract or the suspension of its execution until the obstacle is removed.

\section{Ethical Consideration}

Ethical issues (such as plagiarism, conscious satisfaction, misleading, making and or forging data, publishing or sending to two places, redundancy, etc.) have been fully considered by the writers.

\section{Acknowledgement}

Researchers consider it necessary to thank and appreciate all the participants who helped us in this research.

\section{References}

1. Ahmadpour A (2005). Economic hardship in performance of contracts: a comparative study of English, American, French, and German law and CISG. [Ph.D thesis]. University of Aberdeen, USA.

2. Sadeghi Moghadam MH (2011). Change in contract conditions. Justice Publications, Tehran/ Iran. (In Persian).

3. Emami H (2012). Civil code. 30th Ed. Islamic Publications, Tehran/Iran. (In Persian).

4. Katozian N (2011). General theory of obligations. 19th Ed. Mizan Publications, Tehran/Iran. (In Persian).

5. Mousavi Bojnurdi MK (2001). Collection of jurisprudential, legal, philosophical, and social articles. $1^{\text {st }} \mathrm{Ed}$. Institute for Organizing and Publishing the Works of Imam Khomeini, Tehran/Iran. (In Persian).

6. Alsan M, Najafizadeh L, Hosseini Ashlaqi M, Saburi H (2016). Principles of contract termination in Imami jurisprudence and Iranian law. Judgment; 88. (In Persian).

7. Parsai M (2013). Principles of contract preparation and regulation. $2^{\text {nd }}$ Ed. Tabriz University of Medical Sciences and Health Services Publications. Tabriz/ Iran. (In Persian).

8. Zargani A (2013). Rules for concluding contracts in government agencies. $1^{\text {st }} \mathrm{Ed}$. Publications of the Deputy of Financial Supervision and Deputy Treasury of Khuzestan Province, Khuzestan/Iran. (In Persian). 
9. Rimke J (1999). Force majeure and hardship: Application in international trade practice with specific regard to the CIS G and the UNIDROIT. Principles of International Commercial Contracts, Kluwer. Pp. 201-202.

10. Shafaei MR (2011). A comparative study of changing circumstances in contracts. Phoenix Publication, Tehran/Iran. (In Persian).

11. Katozian N (1997). Civil code: General rules of contracts. $4^{\text {th }} \mathrm{Ed}$. Sahami Enteshar Publication, Tehran/Iran. (In Persian).

12. Sharifi E, Safari N (2010). a comparative study of the hard scheb effect on the principles of European contract law, principles of international commercial contracts and Iranian law. Mofidnameh, 79. (In Persian).

13. Mekki M, Kloepfer Pelese M (2010). Hardship and modification (or 'Revision') of the contract. Available at: https://mustaphamekki.openum.ca/publications/hardship-and-modification-or-revision-of-the-contract. Accessed: 12 Jun 2020.
14. Jowit E (2006). The dictionary of English law. $2^{\text {nd }} \mathrm{Ed}$. Sweet Maxwell, John Bark/ London.

15. Katozian N (2013). General rules of contracts. Enteshar Co, Tehran/Iran. (In Persian).

16. Safaei SH. (1985). Cairo force or force majeure. Legal Journal, 3: 124

17. KhoeiSQ (1412 AH). Al-Figh. Vol. 7. Dar al-Hadi, Beirut. (In Arabic).

18. Katozian N (2013). General rules of contracts. $1^{\text {st }}$ Ed. Enteshar Co, Tehran/Iran. (In Persian).

19. Shahid SM (2016). Fall of obligations. Majd Scientific and Cultural Association, Tehran/Iran. (In Persian).

20. Najafi MH. (1981). Jawnahar al-Kalam in Sharh Sharia al-Islam. Vol. 27. Dar Al-Ahya Al-Tarath Al-Arabi, Beirut.p. 62. (In Arabic). 